Gunnison, J. B., Kunishige, E., Coleman, V. R. \& Jawetz, E. (1955). J. gen. Microbiol. 13, 509-518

\title{
The Mode of Action of Antibiotic Synergism and Antagonism: the Effect in Vitro on Bacteria not Actively Multiplying
}

\author{
By JANET B. GUNNISON, ELEANOR KUNISHIGE, VIRGINIA \\ R. COLEMAN AND E. JAWETZ \\ Department of Microbiology, University of California School of Medicine, \\ San Francisco 22, California, U.S.A.
}

\begin{abstract}
SUMMARY: The synergistic effect of certain pairs of antibiotics might be due to action on 'persisters'; i.e. members of a bacterial population which survive exposure to single drugs, perhaps while in a state of reduced metabolic activity, although their offspring do not show enhanced resistance. Hence, antibiotics were tested in vitro under conditions minimizing bacterial multiplication and metabolism. At $37^{\circ}$, neomycin, polymyxin, and streptomycin were more effective in the absence of nutrients than in nutrient broth; oxytetracycline and bacitracin were equally effective in either environment; but penicillin had little effect in the absence of nutrients. At $4^{\circ}$, bactericidal action varied with the test organism so that differences could not be attributed solely to the 'resting' state of the bacteria. Conditions not permitting bacterial multiplication prevented synergism and those antagonisms demonstrable in broth. Probably synergism depends upon rapid bactericidal action preventing the emergence of persisters rather than upon destruction of these relatively inactive forms.
\end{abstract}

Most studies on the action of antimicrobial drugs in vitro have been made with multiplying bacteria, and the effect of combinations of antibiotics under conditions unfavourable to bacterial growth has not been investigated intensively. Reports on the effectiveness of antibiotics in environments which do not permit active bacterial multiplication seem contradictory, but some of the apparent disagreements are probably due to differences in the techniques used and in the bacteria tested. Thus far, synergism and antagonism among antibiotics have been observed only under conditions which permit growth and multiplication (Jawetz \& Gunnison, 1953). Information about the action of antibiotics on non-multiplying bacteria is particularly needed with regard to so-called 'persisters', a term applied by Bigger (1944) to those members of bacterial populations which survive the action of antimicrobial drugs, although their offspring are no more resistant to the drugs than the original parent culture. A possible explanation for this phenomenon is that persisters may be in a phase of relative metabolic inactivity. As expressed by Davis (1954), '...these cells appear to be genotypically drug-sensitive but phenotypically drug-resistant'. In some chronic disease states, persisters may explain the failure of chemotherapeutic agents to eradicate infection. In certain chronic infections, synergistic drug combinations have resulted in cure, whereas single drugs, even though exhibiting antibacterial action, have failed. Synergism can 
be measured as a function of the bactericidal rate of a combination of drugs against a given organism as compared with the rate of each component. The question arises whether the curative effect of a synergistic combination might be attributed to its ability to kill persisters or to prevent their emergence. To elucidate this problem, antibiotics were tested in vitro under conditions minimizing growth, metabolism and multiplication.

\section{METHODS}

Antibiotics. Bacitracin, neomycin sulphate, and crystalline potassium penicillin G, dihydrostreptomycin sulphate, polymyxin B sulphate, and oxytetracycline hydrochloride (Terramycin) were obtained as sterile dry powders. These were dissolved in sterile double glass-distilled water in concentrated solution and stored at $4^{\circ}$. Dilutions in the respective diluents were prepared aseptically just before use.

Diluents. Dilutions of drugs and suspensions of bacteria were prepared in sterile double glass-distilled water or in Ringer's solution. For certain tests, imidazole buffer solution was prepared by adding $1.75 \mathrm{~g}$. imidazole to $90 \mathrm{ml}$. $0 \cdot 1 \mathrm{~N}$-hydrochloric acid and making up to $100 \mathrm{ml}$. with distilled water. This stock solution was diluted $1 / 10$ and sterilized in the autoclave ( $\mathrm{pH} c .7 \cdot 2)$.

Media. Bacteria were grown in broth composed of proteose peptone No. 3 (Difco), 20 g.; glucose, $0.5 \mathrm{~g}$; sodium chloride, $5 \mathrm{~g}$; disodium phosphate $\left(\mathrm{Na}_{2} \mathrm{HPO}_{4} \cdot 12 \mathrm{H}_{2} \mathrm{O}\right), 5$ g.; water, $1000 \mathrm{ml}$.; $\mathrm{pH} \mathrm{7 \cdot 2}$. Proteose no. 3 agar (Difco) was used for plate counts.

Bacteria. Streptococcus faecalis (strain 16), Staphylococcus aureus (strains Heatley and De), Klebsiella pneumoniae (strain AD), and Escherichia coli (strain Da) were used.

Procedure. The bacteria were inoculated into broth and incubated at $37^{\circ}$ for $18 \mathrm{hr}$. The organisms were then washed twice in the respective diluent and uniformly resuspended therein to give a turbidity equal to that of the original $18 \mathrm{hr}$. culture. Dilutions of antibiotics were added to tubes of sterile glassdistilled water, Ringer's solution, or imidazole buffer. Each tube was then inoculated with the washed suspension of the test bacteria to give $10^{6}-10^{8}$ organisms $/ \mathrm{ml}$. in a total volume of $15 \mathrm{ml}$. Similar tubes containing broth were inoculated with the unwashed bacterial culture for comparison. Samples were withdrawn at $0,4,7,24$, and $30 \mathrm{hr}$. of exposure at either $4^{\circ}$ or $37^{\circ}$ and the number of viable organisms was determined by the usual plate count procedure. Differences between counts of less than tenfold ( 1 log unit) were regarded as insignificant.

Definitions. The 'minimal bactericidal dose' is defined as the smallest amount of antibiotic which resulted in a bacterial count significantly lower than that of the drug-free control at the time of sampling and also lower than the initial count immediately after inoculation in at least two successive determinations within $30 \mathrm{hr}$. of exposure to the drug. 'Synergism' is defined as follows: 'The addition of one drug to another results in a marked increase in bactericidal rate within the first 8-24 hr. of exposure in vitro, and the bac- 
tericidal rate of the combination is more rapid than that of twice the concentration of each single drug participating in the mixture' (Jawetz \& Gunnison, 1953). 'Addition' refers to a somewhat more rapid bactericidal rate with a combination of drugs than with either drug alone but no more rapid than that of twice the concentration of the more active single drug alone or than that of the optimal dose of drugs showing a zone effect. 'Indifference' means that the bactericidal rate of a combination is the same as that of the more active drug alone. 'Antagonism' is defined as a less rapid bactericidal rate with a combination than with the more active drug alone.

\section{RESULTS}

\section{Effects of single antibiotics}

The bactericidal effect of the various antibiotics on washed bacteria suspended in distilled water at $37^{\circ}$ as compared with their effect in nutrient broth is summarized in Table 1. In making such comparisons, it must be remembered that not only was there no demonstrable multiplication of the test bacteria in water but a significant number of the population of some of the test strains died within $24 \mathrm{hr}$, even in the absence of antibiotics (Fig. 1). Hence, the drug may merely accelerate the death-rate obtained in water alone, thus magnifying the apparent difference under the two conditions.

Table 1. Effect of medium on bactericidal action of various antibiotics at $37^{\circ}$

\begin{tabular}{|c|c|c|c|c|c|c|c|c|c|c|c|c|}
\hline \multirow{3}{*}{ Organism } & \multicolumn{12}{|c|}{ Minimal bactericidal dose* in } \\
\hline & \multicolumn{2}{|c|}{ Neomycin } & \multicolumn{2}{|c|}{ Polymyxin } & \multicolumn{2}{|c|}{ Streptomycin } & \multicolumn{2}{|c|}{$\begin{array}{l}\text { Oxytetra- } \\
\text { cycline }\end{array}$} & \multicolumn{2}{|c|}{ Bacitracin } & \multicolumn{2}{|c|}{ Penicillin } \\
\hline & Broth & Water & Broth & Water & Broth & Water & Broth & Water & Broth & Water & Broth & Water \\
\hline $\begin{array}{l}\text { Streptococcus } \\
\text { faecalis } \text { strain } \\
16\end{array}$ & $>500$ & $0 \cdot 05$ & $>500$ & 5 & 500 & 20 & 20 & $\mathbf{5}$ & 2 & 10 & $\mathbf{5}$ & $>500$ \\
\hline $\begin{array}{l}\text { Staphylococcus } \\
\text { aureus Heatley }\end{array}$ & 25 & 0.5 & 500 & $<5$ & 100 & 5 & 5 & 2 & 2 & 5 & 0.01 & 500 \\
\hline S. aureus De & 10 & 1 & $>100$ & $0 \cdot 5$ & 50 & 10 & 2 & 2 & 2 & 2 & $>500$ & 500 \\
\hline $\begin{array}{l}\text { Klebsiella } \\
\text { pneumoniae } \mathrm{AD}\end{array}$ & D & $<0 \cdot 5$ & $0 \cdot 5$ & $0 \cdot 05$ & 5 & 1 & 5 & 5 & $>20$ & $<5$ & 1 & $>50$ \\
\hline $\begin{array}{l}\text { Escherichia } \\
\text { coli } \mathrm{Da}\end{array}$ & 10 & $0 \cdot 25$ & 5 & 2 & 100 & 5 & $>\mathbf{2 0}$ & 10 & 100 & 100 & $>10$ & 500 \\
\hline
\end{tabular}

* As defined p. 510. Penicillin and bacitracin expressed in units $/ \mathrm{ml}$.; other drugs in $\mu \mathrm{g} . / \mathrm{ml}$.

Neomycin, as previously reported (Gunnison, Kunishige \& Jawetz, 1954), was more active in water than in broth. The difference in activity in the two environments varied with the test micro-organisms and was greatest with Streptococcus faecalis strain 16 against which this antibiotic had no effect in broth. An optimal zone of bactericidal effect was shown in water but not in broth against $S$. faecalis strain 16 and the two strains of Staphylococcus aureus tested, but not against the two Gram-negative rods. For example, with 
$S$. aureus strain Heatley, concentrations of 5-10 $\mu \mathrm{g} . / \mathrm{ml}$. killed more rapidly in water than did either lower or higher amounts (Fig. 1).

Likewise, polymyxin was far more active in water than in nutrient broth in terms of either the bactericidal rate or of the minimal bactericidal dose. With streptomycin, the difference in the two environments was less marked, but the minimal dose was 5-25 times lower in water than in broth. No optimal zone was noted with either drug.

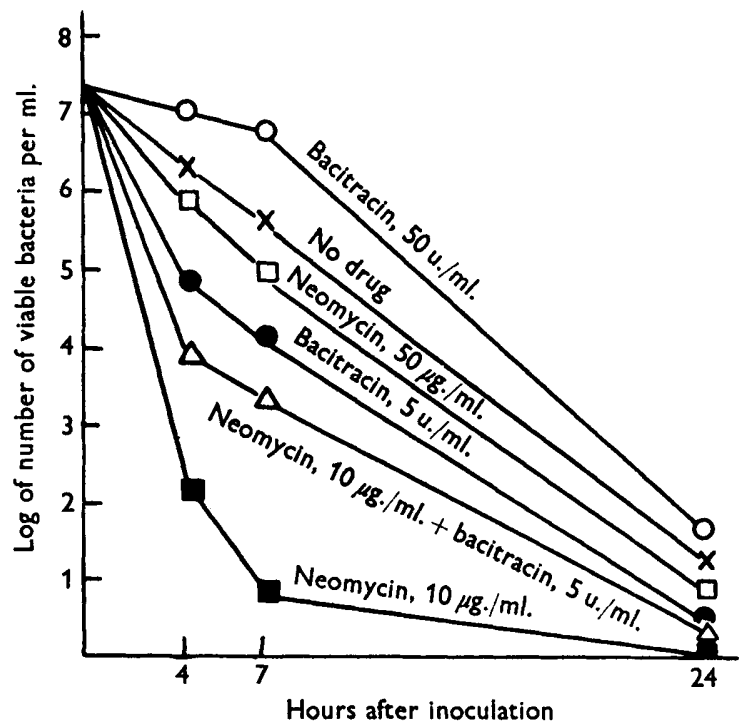

Fig. 1. Bactericidal action of neomycin and bacitracin on Staphylococcus aureus strain Heatley suspended in distilled water at $37^{\circ}$, showing zone phenomenon. Neomycin is more rapidly bactericidal at a concentration of $10 \mu \mathrm{g} . / \mathrm{ml}$. than at $50 \mu \mathrm{g} . / \mathrm{ml}$.; bacitracin, at 5 units $/ \mathrm{ml}$. than at 50 units $/ \mathrm{ml}$. Bacitracin interferes with the bactericidal effect of neomycin. The organisms die more rapidly in the drug-free control than in bacitracin (50 units/ml.).

Oxytetracycline showed approximately the same degree of bactericidal action on organisms suspended in either water or broth with a slight tendency toward a greater effect in water. There was no zone detectable.

Bacitracin did not differ sharply in its ability to kill bacteria in broth or in water, although it was slightly more active in the former. A zone effect was shown in water with the two strains of staphylococci as has been reported (Gunnison et al. 1954). With Staphylococcus aureus strain Heatley, the bactericidal rate of concentrations of bacitracin greater than the optimum was actually slower than that in water alone; i.e. the drug seemed to protect the organisms from the harmful effect of water and this may be responsible for the apparent zone (Fig. 1).

Penicillin, as expected, was far more effective in broth, although large doses $(50-500 \mu \mathrm{g} . / \mathrm{ml}$.) had a bactericidal effect on some strains in water. As observed before a zone was shown with Streptococcus faecalis strain 16 only in broth (Gunnison, Jawetz \& Coleman, 1950). 
In summary, the six antibiotics showed a scale of activity in water as compared to that in broth, ranging from neomycin, polymyxin, and, to a less extent, streptomycin, which were more active in water; oxytetracycline and bacitracin which were almost equally active in water or broth; to penicillin which had little or no effect in water.

Table 2. Effect of temperature on the bactericidal action of antibiotics in water and in broth

\begin{tabular}{|c|c|c|c|c|c|c|c|c|c|c|c|c|}
\hline \multirow[b]{3}{*}{ Organism } & \multicolumn{12}{|c|}{ Minimum bactericidal dose* at } \\
\hline & \multicolumn{2}{|c|}{ Neomycin } & \multicolumn{2}{|c|}{ Polymyxin } & \multicolumn{2}{|c|}{ Streptomycin } & \multicolumn{2}{|c|}{ Oxytetracycline } & \multicolumn{2}{|c|}{ Bacitracin } & \multicolumn{2}{|c|}{ Penicillin } \\
\hline & $37^{\circ}$ & $4^{\circ}$ & $37^{\circ}$ & $4^{\circ}$ & $37^{\circ}$ & $4^{\circ}$ & $37^{\circ}$ & $4^{\circ}$ & $37^{\circ}$ & $4^{\circ}$ & $37^{\circ}$ & $4^{\circ}$ \\
\hline & \multicolumn{12}{|c|}{ In water } \\
\hline S. faecalis 16 & 0.05 & $>500$ & $\mathbf{5}$ & $>500$ & 20 & $>\mathbf{5 0 0}$ & $\mathbf{5}$ & $>500$ & 10 & $>\mathbf{5 0 0}$ & $>500$ & $>\mathbf{5 0 0}$ \\
\hline $\begin{array}{l}\text { S. aureus } \\
\text { Heatley }\end{array}$ & 0.5 & 1 & $<5$ & $>500$ & $\mathbf{5}$ & 20 & 2 & 500 & $\mathbf{5}$ & $>500$ & 500 & $>500$ \\
\hline \multirow[t]{2}{*}{ E. coli $\mathbf{D a}$} & $0 \cdot 25$ & $0 \cdot 5$ & $\mathbf{2}$ & $<5$ & $\mathbf{5}$ & $\mathbf{5}$ & 10 & 500 & 100 & 500 & 500 & $>500$ \\
\hline & \multicolumn{12}{|c|}{ In broth } \\
\hline S. faecalis 16 & $>\mathbf{5 0 0}$ & $>500$ & $>\mathbf{5 0 0}$ & $>500$ & 500 & $>500$ & 20 & $>500$ & 2 & $>500$ & $\tilde{\mathbf{z}}$ & $>500$ \\
\hline $\begin{array}{l}\text { S. aureus } \\
\text { Heatley }\end{array}$ & 25 & 50 & $>500$ & $>500$ & 100 & 500 & $\mathbf{5}$ & $>500$ & 2 & $>500$ & 0.01 & $>\mathbf{5 0 0}$ \\
\hline E. coli $\mathbf{D a}$ & 10 & 20 & 5 & 5 & 100 & 500 & $<500$ & $>500$ & 100 & $>100$ & $<500$ & $>500$ \\
\hline
\end{tabular}

* As defined p. 510. Penicillin and bacitracin expressed in units $/ \mathrm{ml}$.; other drugs in $\mu \mathrm{g} . / \mathrm{ml}$.

In order to test the hypothesis that the effectiveness of the drugs was related to bacterial multiplication, tests were made at $4^{\circ}$, a temperature which inhibited detectable growth of the organisms (Table 2). At this low temperature, the bactericidal effect of the antibiotics varied widely with the microorganism, as shown in Table 2. For example, at $4^{\circ}$ Streptococcus faecalis strain 16 was resistant to all six drugs tested (Fig. 2); whereas Staphylococcus aureus Heatley was killed by neomycin and by streptomycin in concentrations only slightly greater than those required at $37^{\circ}$ in water. Hence, the greater effect at $37^{\circ}$ of certain antibiotics in water than in nutrient media cannot be attributed solely to the non-multiplying resting state of the bacteria.

In a number of tests, bacteria which were not sensitive to a given antibiotic at $4^{\circ}$ were first exposed to its action for $4-48 \mathrm{hr}$. at $37^{\circ}$ and then refrigerated at $4^{\circ}$ or vice versa. The bactericidal effect initiated at $37^{\circ}$ was arrested promptly by refrigeration, and there was no further decrease in the number of viable organisms within $72 \mathrm{hr}$. at the lower temperature. On the other hand, with organisms exposed first at $4^{\circ}$ the bacterial population remained unchanged for as long as $48 \mathrm{hr}$.; but upon placing at $37^{\circ}$, bactericidal action occurred (Fig. 2) sometimes more rapidly than with bacteria not previously refrigerated.

The effect of $\mathrm{pH}$ value is one of the many factors which must be considered, especially when comparing tests made in unbuffered water with those in broth

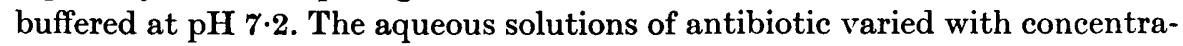


tion from $\mathrm{pH} 5 \cdot 5$ to $7 \cdot 0$ except for oxytetracycline which fell to $\mathrm{pH} \mathbf{3 \cdot 7}-\mathbf{3} \cdot \mathbf{0}$ in concentrations of 50-500 $\mu \mathrm{g} . / \mathrm{ml}$. All the antibiotics used were stable for the period of experiment in the range of $\mathrm{pH}$ tested. There was no consistent correlation between the variations in $\mathrm{pH}$ and the bactericidal action or the occurrence of the zone phenomenon.

Attempts to carry out tests in Ringer's solution were often unsuccessful because some of the test bacteria, especially the staphylococci, tended to die out rapidly in the absence of drug. Furthermore, both sodium and potassium

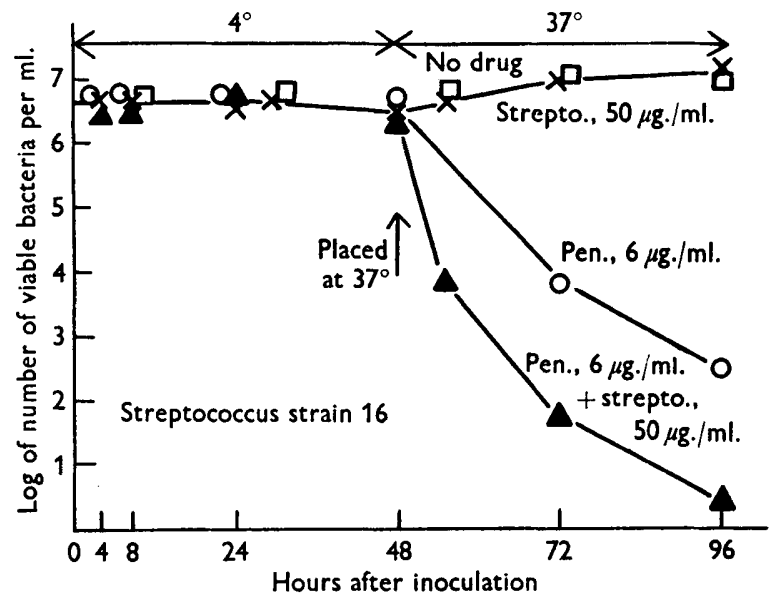

Fig. 2. Effect of temperature on bactericidal action of penicillin and streptomycin on Streptococcus faecalis strain 16 in broth. At $4^{\circ}$, these drugs have little effect alone or in combination. At $37^{\circ}$, the combination kills more rapidly than the optimal concentration of penicillin alone; i.e. synergism occurs.

salts interfered with the action of certain antibiotics, notably with that of neomycin (Gunnison et al. 1954). With those drugs and bacteria where Ringer's solution could be used, the results obtained were essentially the same as those in water. In imidazole buffer at $\mathrm{pH} \mathbf{7 \cdot 2}$, the test organisms survived in the drug-free control and the buffer did not interfere with drug action. The bactericidal action of the various antibiotics in this buffer was usually similar to that in water.

\section{Effects of pairs of antibiotics}

Representative pairs of antibiotics known to show either synergism or antagonism when acting on certain bacteria in broth were tested for their combined effect on bacteria suspended in water at $37^{\circ}$ with the results summarized in Table 3. The marked synergistic effects sometimes shown in broth were never demonstrable with non-multiplying bacteria in water. Mixtures such as penicillin + streptomycin, which were strongly synergistic when acting on Streptococcus faecalis strain 16 in nutrient medium, gave only addition or even indifference in water (Fig. 3). Even with those pairs where one or both drugs exerted a bactericidal action in non-nutrient solutions, synergism did 
not occur. For example, streptomycin + neomycin or oxytetracycline were synergistic against Staphyococcus aureus in broth but not in water, in spite of the ability of these drugs to kill the organisms in either environment.

Table 3. Effect of combinations of antibiotics on bacteria exposed in nutrient broth and in water

\begin{tabular}{|c|c|c|c|c|c|c|c|c|}
\hline \multirow{2}{*}{ Antibiotics tested } & \multicolumn{2}{|c|}{ S. faecalis 16} & \multicolumn{2}{|c|}{ S. aureus $\mathbf{H}$. } & \multicolumn{2}{|c|}{ S. aureus De } & \multicolumn{2}{|c|}{ E. coli $\mathrm{Da}$} \\
\hline & Broth & Water & Broth & Water & Broth & Water & Broth & Water \\
\hline $\begin{array}{l}\text { Penicillin } \\
\quad \text { + streptomycin } \\
\text { + neomycin } \\
\text { + bacitracin } \\
\text { + oxytetracycline }\end{array}$ & $\begin{array}{l}\text { Syn. } \\
\text { Syn. } \\
\text { Syn. } \\
\text { Antag. }\end{array}$ & $\begin{array}{l}\text { Add. } \\
\text { Antag. } \\
\mathbf{0} \\
\mathbf{0}\end{array}$ & $\begin{array}{c}\text { Syn. } \\
- \\
\text { Syn. } \\
\text { Antag. }\end{array}$ & $\begin{array}{l}\text { Add. } \\
\text { Add. } \\
\overline{0}\end{array}$ & $\begin{array}{l}\mathbf{0} \\
\mathbf{0} \\
\mathbf{0} \\
\mathbf{0}\end{array}$ & $\begin{array}{l}0 \\
0 \\
0 \\
-\end{array}$ & $\begin{array}{l}0 \\
\overline{0} \\
0\end{array}$ & $\begin{array}{l}- \\
- \\
-\end{array}$ \\
\hline $\begin{array}{l}\text { Streptomycin } \\
\text { + neomycin } \\
\text { + bacitracin } \\
\text { + oxytetracycline } \\
\text { + polymyxin }\end{array}$ & $\begin{array}{c}0 \\
\text { Syn. } \\
0 \\
-\end{array}$ & $\begin{array}{l}\text { Add. } \\
\text { Add. } \\
\text { Add. } \\
\text { Add. }\end{array}$ & $\begin{array}{l}\text { Syn. } \\
\text { Syn. } \\
\text { Syn. } \\
-\end{array}$ & $\begin{array}{c}\text { Add. } \\
\text { o } \\
\text { Antag. } \\
-\end{array}$ & $\begin{array}{l}\text { Syn. } \\
\text { Syn } \\
\text { Syn. } \\
-\end{array}$ & $\begin{array}{c}\text { Add. } \\
0 \\
\text { Antag. } \\
-\end{array}$ & $\begin{array}{c}0 \\
0 \\
0 \\
\text { Syn. }\end{array}$ & $\begin{array}{c}\text { Add. } \\
0 \\
0 \\
\text { Add. }\end{array}$ \\
\hline $\begin{array}{l}\text { Neomycin } \\
\quad \text { + bacitracin } \\
\quad \text { +oxytetracycline } \\
\text { + polymyxin }\end{array}$ & $\begin{array}{c}\text { Syn. } \\
- \\
-\end{array}$ & $\begin{array}{l}\text { Add. } \\
\text { Add. }\end{array}$ & $\begin{array}{l}\text { Syn. } \\
\text { Syn. }\end{array}$ & $\begin{array}{c}\text { Antag. } \\
\text { Antag. } \\
-\end{array}$ & $\begin{array}{l}\text { Syn. } \\
\text { Syn. }\end{array}$ & $\begin{array}{c}\text { Antag. } \\
- \\
-\end{array}$ & $\begin{array}{l}- \\
-\end{array}$ & $\begin{array}{c}0 \\
\text { Add. } \\
0\end{array}$ \\
\hline $\begin{array}{l}\text { Bacitracin } \\
\quad+\text { oxytetracycline }\end{array}$ & - & Add. & Syn. & Antag. & Syn. & Antag. & 0 & 0 \\
\hline $\begin{array}{c}\text { Oxytetracycline } \\
\text { + polymyxin }\end{array}$ & - & Add. & - & - & - & - & Syn. & 0 \\
\hline
\end{tabular}

Syn. $=$ synergism $;$ Antag. $=$ antagonism; Add. $=$ addition $; 0=$ indifference; these terms are defined on p. 510. $-=$ not tested.

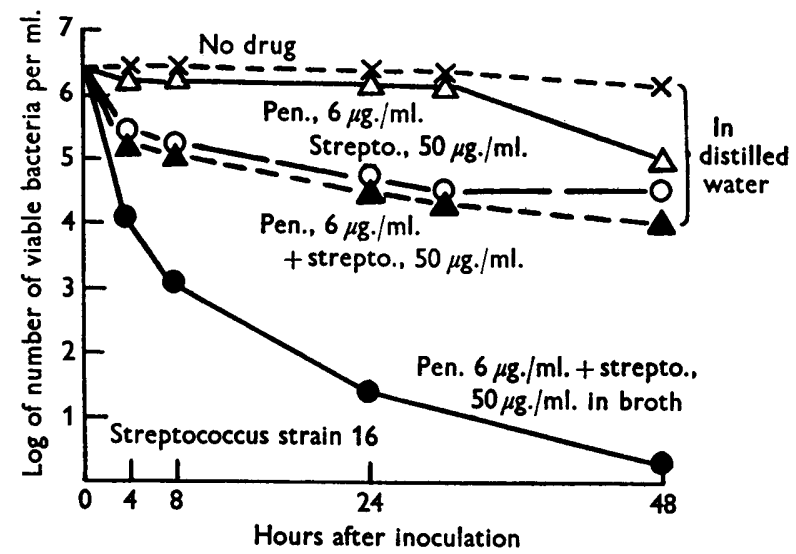

Fig. 3. Effect of medium on bactericidal action of penicillin and streptomycin on Streptococcus faecalis strain 16 at $37^{\circ}$. In distilled water, these drugs have little effect either alone or in combination. In broth, synergism occurs.

Mixtures which were antagonistic in broth, such as penicillin +oxytetracycline, were entirely indifferent in water. This was to be expected because, although inhibitory concentrations of oxytetracycline interfered with the 
bactericidal action of penicillin in broth, penicillin had no effect in water, so that it could not be antagonized. On the other hand, some pairs synergistic in broth appeared to be antagonistic in water. This was noted especially with bacitracin + oxytetracycline or neomycin and seemed due in part to the fact that the bacteria died more slowly in the presence of bacitracin than in the drug-free control (Fig. 1). Mixtures of streptomycin or neomycin + oxytetracycline in certain concentrations also were less effective together than alone against 'resting' staphylococci. In water and in buffer, penicillin interfered with the action of optimal amounts of neomycin on Streptococcus faecalis strain 16, although giving an additive effect with both lower and higher concentrations.

In a limited series of tests, bacterial growth was inhibited by holding at $4^{\circ}$ in either broth or water. At this low temperature, no combined action other than occasional slight addition was observed even when one or both drugs showed a bactericidal effect when acting alone. With organisms first exposed to a pair of drugs at $37^{\circ}$ and then refrigerated, the initial synergistic or antagonistic action was arrested. With organisms first exposed to two drugs at $4^{\circ}$ and then transferred to the incubator, the usual sequence of events at $37^{\circ}$ took place (Fig. 2). In tests made in Ringer's solution or in imidazole buffer the results were essentially the same as those in water. Thus it is unlikely that differences in $\mathrm{pH}$ were an important factor in these tests.

\section{DISCUSSION}

The bactericidal action of antibiotics in nutrient broth seems related in some degree to their effects in vivo, but their action in water or in buffer solutions probably reflects physical effects not operative in vivo. Hence, the latter experimental approach can give only limited answers concerning antibiotic action on non-multiplying bacteria in the body. An antibiotic might exert two effects on bacteria differing with concentration and conditions; one influencing their metabolism and the other altering their physical integrity.

The more rapid bactericidal action of neomycin and polymyxin in water than in broth may not be related to the resting state of the bacteria because when multiplication was suppressed by lowering the temperature in broth, the bactericidal rate was never increased and might be decreased. The action of these antibiotics in water or in buffer is probably not related to biosynthesis of actively metabolizing bacteria. Physical surface effects, disturbing osmotic equilibrium of the cell wall, have been demonstrated for polymyxin (Few \& Schulman, 1953; Newton, 1954).

Although it has been established that penicillin is most effective against multiplying bacteria (Hobby, Meyer \& Chaffee, 1942; Lee, Foley \& Epstein, 1944), the situation with streptomycin is less clear. Garrod (1948) found that streptomycin had little effect at $5^{\circ}$ in broth. Most workers have found streptomycin to be more effective against multiplying bacteria than against those in water or in salt solution (Hamre, Rake \& Donovick, 1946; Hobby \& Lenert, 1947; Strauss, 1947; Davis, 1954), a finding not confirmed here. This disagreement may be due partly to the strains tested. 
Failure of streptomycin, neomycin, and polymyxin to kill some of the test bacteria rapidly in nutrient broth, although doing so in water, may be due in part to an interfering action of salts (Berkman, Henry \& Housewright, 1947; Schoenhard \& Stafseth, 1953; Newton, 1954). Although streptomycin and neomycin are known to increase in activity with $\mathrm{pH}$ value in nutrient broth (Waksman, Bugie \& Schatz, 1944; Waksman \& Lechevalier, 1949), there was no correlation between $\mathrm{pH}$ and bactericidal action in water.

Difficulties in interpreting the influence of various factors are increased when simultaneous action of two antibiotics is considered. Antagonism between two antibiotics had not been observed previously in the absence of multiplication (Jawetz \& Gunnison, 1953). Although none of the pairs antagonistic in broth showed this effect in water, oddly some pairs synergistic in broth showed antagonism in a narrow range of concentrations in the absence of nutrients.

Inasmuch as synergistic action could not be demonstrated against nonmultiplying bacteria, it seems unlikely that persisters are affected by combinations of drugs or that synergism in broth and in vivo is due to specific destruction of these members of a bacterial population. It seems more probable that in synergism in broth the bactericidal rate is so rapid that all exposed bacteria are killed before any of them enter into the state of reduced metabolic activity believed to be characteristic of the persister.

We are grateful to Dr E. L. Burbidge (The Upjohn Company) for neomycin, to Dr F. C. Fink (Chas. Pfizer \& Co., Inc.) for antibiotic diagnostic kits, to Dr Mary $B$. Glendening for helpful advice regarding buffer solutions, and to Dorothy Groom for technical assistance. This work was supported in part by grants from the U.S. Public Health Service (E-214) and from the University of California School of Medicine.

\section{REFERENCES}

Berkman, S., Henry, R. J. \& Housewright, R. D. (1947). Studies on streptomycin. I. Factors influencing the activity of streptomycin. J. Bact. 53, 567.

BigGer, J. W. (1944). Treatment of staphylococcal infections with penicillin by intermittent sterilization. Lancet, ii, 497.

DAvis, B. D. (1954). Metabolic factors affecting chemotherapeutic response. N.Y. Acad. Med. Symp. no. 8. Cellular metabolism and infections. New York: Academic Press, Inc. 79.

Few, A. V. \& Schulman, J. H. (1953). The absorption of polymyxin E by bacteria and bacterial cell walls and its bactericidal action. J. gen. Microbiol. 9, 454 .

Garrod, L. P. (1948). The bactericidal action of streptomycin. Brit. med. J. i, 382.

Gunnison, J. B., Jawetz, E. \& Coleman, V. R. (1950). The effect of combinations of antibiotics on enterococci in vitro. J. Lab. clin. Med. 36, 900.

Gunnison, J. B., Kunishige, E. \& Jawetz, E. (1954). Bactericidal action of neomycin on non-multiplying bacteria: optimal zone phenomenon. Antibiotics Annual. Med. Encyclopedia, N.Y., 190.

Hamre, D., Rake, G. Y. \& Donovick, R. (1946). Bactericidal action of streptomycin. Proc. Soc. exp. Biol. N.Y. 62, 25.

Hoввy, G. L. \& Lenert, T. F. (1947). Observations of the action of streptomycin in vitro (II). Proc. Soc. exp. Biol. N.Y. 65, 242.

Hobby, G. L., Meyer, K. \& Chaffee, E. (1942). Observations on the mechanism of action of penicillin. Proc. Soc. exp. Biol., N.Y. 50, 281. 
JAwetz, E. \& Gunnison, J. B. (1953). Antibiotic synergism and antagonism: an assessment of the problem. Pharm. Rev. 5, 175.

Lee, S. W., Foley, E. J. \& Epstein, J. A. (1944). Mode of action of penicillin I. Bacterial growth and penicillin activity-Staphylococcus aureus F.D.A. J. Bact. 48, 393.

Newton, B. A. (1954). Site of action of polymyxin on Pseudomonas aeruginosa: antagonism of cations. J. gen. Microbiol. 10, 491.

Schoenhard, H. E. \& STafseth, H. J. (1953). Some observations on the in vitro action of neomycin. Antibiot. and Chemother. 3, 41.

Strauss, E. (1947). 'In vitro' observations of mode of action of streptomycin. Proc. Soc. exp. Biol., N.Y. 64, 57.

Waksman, S. A., Bugie, E. \& Schatz, A. (1944). Isolation of antibiotic substances from soil micro-organisms, with special reference to streptothricin and streptomycin. Proc. Mayo Clin. 19, 537.

Waksman, S. A. \& Lechevalier, H. A. (1949). Neomycin, a new antibiotic active against streptomycin-resistant bacteria, including tuberculosis organisms. Science, 109, 305.

(Received 7 June 1955) 